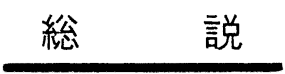

\title{
カチオンテロメリゼーション
}

\author{
浅 原 照 三・术瀨秀 犬
}

束宗大学生産技術研究所（果京都港区六本木 7-22-1）

\section{Cationic Telomerization}

Teruzō AsAHARA and Hideo Kise

Institute of Industrial Science, The University of Tokyo

(7-22-1, Roppongi, Minato-ku, Tokyo)

\section{1 はじめに}

テロメリセーションは, 連鎖移動起数り大きい浴媒中 でのモノマーの重合发忘で尚り，一般的に次のように表 わすこレができる。

$$
\mathrm{XY} \because n \mathrm{M} \rightarrow \mathrm{XM}_{n} \mathrm{Y}
$$

ここで XY は軏鎖移動剂(テローゲン)であり，M注 モノマー(タクソードン), 生成物の $\mathrm{XM}_{n} \mathrm{Y}$ はテロマ-

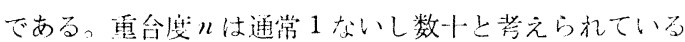
が上くに限が走めら机ているわけでは尔い

1940 年代に du Pont 社の何究者により，エチレン上 八ロゲン化台物のテロメリゼーションに関する一連の塟

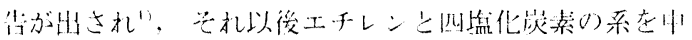
心として，国の内外で多数の研究が行なわれてきた。こ の種の反応は大部分がラジカル機構で進み，テローゲン として各種の八ロゲン化合物，アルコールなどが用いら れ，多くのテローゲンについて連鎖移動定数が測定され ている。

一方，イオンテロメリゼーションにはカチオンテロ人 リゼーションとアニオンテロメリゼーションがあり，前 者は 1950 年代に入，てからソ連の研究者によりはじめ て系統的に研究された。すなおち, イソプレン，ブタジ エン，クロロプレンなどをタクソーゲンとして用い，ア リル型ハロゲン化合物をテローゲンとするカチオンテロ メリゼーションである。その後, 有機酸やアルデヒドな どもテローダンとして用いられるようにないた。

ラジカルテロメリゼーションが, 重合反忘における連 鎖移動の研究から発䐎してきたのに対して，カチオンテ ロメリゼーションはオレフィンの炭素-炭素二重結合に 対する極性化合物のカチオン付加反応の栍念と密接な関 係をものて発展してきたと考えることができる。尖際こ れまで力チオンテロメリゼージンとして報告されてき た皮灾の中には，タクソーゲンとテローゲンの1対 10

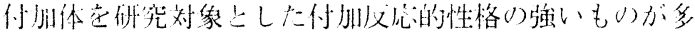
い。もち万んこれらの仅応に打いても，テロマーの生成 を連鎖移動機構により解釈することも叮能であるが，力 チオンテロメリゼーションにおいては，生長鎖の末端近 勏に対アニオンが存在するため，ラジカルテロメリゼ一 ションとは仅応の様相が異なる。カチオン的な連鎖移動 定数の測定されている化合物の種類も少ない。

カチオンテロメリゼーションをラジカルテロメリゼー ションと比較したとき，一般的に次のような特徴をあけ ることができる。

1) 多くの埸合室温またはそれ以トで住忍速度が允分 大きい。

2) 極性化合物，たとえばカルボン酸のＯ－H などは ラジカル的に分制されにくいすす交わちラジカルテロね リゼーションのテローゲンとしてい移動定数が小さい が，力チオン的には移動定数が大きい。

3）2）と逆に極性の小さい化合物はテローゲンこして 不適であり，したがって多官能性化合物，たとえばポリ 八ロゲン化合物などはテローゲンとしてあまり適当でな く, このため多官能性化合物はラジカルテロメリゼー ションと比較して合成しにくい。

4）溶媒効果が大きい。

5）不安定なカルボニウムイオンを経由して反志が進 むため副反応が比較的多い。また，反応機構に不明な点 が多い。

6) 対イオンの影響により分子量分布を規制するこ と，またテロマーに立体規則性をもたせることも可能と 考えられる。ただし，この方面の研究はまだほとんど行 なわれていない。

本報では，以下にカチオンテロメリゼーションの愯略 を説明し，つぎにタタソーゲン別にこれまでの研究結果 をまとめることにする。なお，ラジカル2゙およびアニオ ンテロメリゼーションいについては総説が発表されてい るので参照されたい。 


\section{2 カチオンテロメリゼーションの概要}

\section{$2 \cdot 1$ 反応機構}

カチオンテロメリゼーションの反応機構については, 陆細な研究の報告がみあたらないが，代表的な反忘例之 して，金属八ロゲン化物 $\left(\mathrm{MeX}_{m}\right)$ を開始剤とし，八口 ゲン化物 $(\mathrm{XY})$ をテローゲン，オレフィン (M) をタク ソーダンとするカチオンテロメリゼーションについて は、下記のような機構を考えることができる。

開始反応:

$$
\begin{aligned}
& \mathrm{MeX}_{m}+\mathrm{XY} \rightleftarrows \mathrm{Y}^{+} \ldots \mathrm{MeX}^{-}{ }_{m+1} \\
& \mathrm{Y}^{+} \ldots \mathrm{MeX}^{-}{ }_{m+1}+\mathrm{M} \rightarrow \mathrm{YM}^{+} \cdot \ldots \mathrm{MeX}^{-}{ }_{m+1}
\end{aligned}
$$

生長反灾:

$$
\begin{aligned}
& \mathrm{YM}^{+} \cdots \mathrm{MeX}^{-}{ }_{m+1}+(n-1) \mathrm{M} \\
& \rightarrow \mathrm{YM}_{n}{ }^{+} \cdots \mathrm{MeX}^{-}{ }_{m+1}
\end{aligned}
$$

連鎖移動反忍：

$$
\mathrm{YM}_{n}+\cdots \mathrm{MeX}^{-}{ }_{m+1}+\mathrm{XY}
$$

$$
\text { .. } \mathrm{YM}_{n} \mathrm{X}+\mathrm{Y}^{+}+\cdots \mathrm{MeX}^{-}{ }_{m+1}
$$

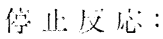

$$
\mathrm{YM}_{n}+\cdots \mathrm{MeX}_{m+1} \cdots \mathrm{YM}_{n} \mathrm{X}+\mathrm{MeX}_{m}
$$

この反応機構は, $\mathrm{MeX}_{m}$ を触媒とし, $\mathrm{XY}$ を共触媒と するカチオン重合反応の機構と形の上ではまったく同じ である。したがって, 各素反応についてもカチオン重合 における研究結果を参考にして考察を進めることができ るが，とくにカチオンテロメリゼーションでは, 開始, 速鎖移動および停止文応が興味の対象となる。

開始反応では，金属八ロゲン化物によりテローゲンか らハロゲン原子が引き抜かれ，カルボニウムイオン $\mathrm{Y}^{+}$ が生成する。のの态は金属八ロゲン化物の親電子性, テローダン中の X の親核性，生成するイオンの安定性 (共鳴および溶媒和等)により平衡の傾き具合が決まる。

他方, 過塩素酸を開始剂とし, 酢酸をテローゲンとす るテロメリゼーションのような場合には23), 過塩素酸か らのプロトンが直接反応を開始すると考えられる（式 7)。またハロゲン化酢酸のように開始剤とテローゲンを 兼ねる場合もある(式 8$)^{18 \mathrm{c}) 。 ~}$

$$
\begin{aligned}
& \mathrm{CH}_{3} \mathrm{COOH}+\mathrm{CH}_{2}=\mathrm{CHPh} \\
& \stackrel{\mathrm{HClO}_{4}}{\longrightarrow} \mathrm{H}-\left(\mathrm{CH}_{2}-\mathrm{CHPh}\right)_{n} \mathrm{OCOCH}_{3} \\
& \stackrel{\mathrm{CH}_{3}}{\longrightarrow} \\
& \mathrm{Cl}_{2} \mathrm{CHCOOH}+\mathrm{CH}_{2}=\stackrel{\mathrm{C}}{-}-\mathrm{CH}=\mathrm{CH}_{2} \\
& \rightarrow \mathrm{H}-\left(\mathrm{C}_{5} \mathrm{H}_{8}\right)_{n} \mathrm{OCOCHCl}{ }_{2}
\end{aligned}
$$

カチオン重合において生長カルボニウムイオンが遊離 イオンか, 対アニオンとイオン対を形成しているかは溶 媒の作用とも関連してしばしば議論の対象となってい る。しかし少なくとも一部はイオン対を形成すると考え られるので゙6)，対アニオンの構造および安定性がテロマ 一の重合度にも影響を与えることが充分予想される。す なわち, 対アニオンの安定性が増すにしたがって生長お
よび移動反忘は容易となり，安定性が減少すると再結合 による停止反忘が活発になる。また生言末端の周囲に存 在する溶媒の塩基性も関連してくると思われる。

テロマーが最終的に生成する段階は連鎖移動 (5) と停 止反応 (6) である。(5) と（6）がどのような比率で起こ るかは興味ある問題であるが，生成するテロマーは同一 である。たとえば，スチレンのカチオン重合において は，対アニオンとの反忘による停止反応と生長反応との 速度定数比 $\left(k_{t} / k_{p}\right)$ が求められているが，その值は $10^{-2}$ のオーダーである ${ }^{37)}$ 。カチオンテロメリゼーションの場 合には, 通常用いられるテローゲンへの移動定数比 $\left(k_{r}\right)$ $\left.k_{p}\right)$ は 1〜10のオーダーと考えられるので, 連鎖移動の 割合が大きいと考えられる。この問題については, 動力 学的研究や，同位元素を有するテローゲンを用いる研究 などが有用と考えられるが，まだほとんど研究されてい ない。

そのほか,生長末端からのプロトン脱離により, 末端に テローバンの断片を有しない特成物を得石徣合もある。

$$
\begin{aligned}
& \mathrm{YM}_{n}+\cdots \mathrm{MeX}_{m+1} \rightarrow \mathrm{YM}_{n}+\mathrm{HX}+\mathrm{MeX}_{m} \text { (9) } \\
& \mathrm{YM}_{n}+\cdots \mathrm{MeX}^{-}{ }_{m+1}+\mathrm{M} \\
& \rightarrow \mathrm{YM}_{n}+\mathrm{HM}^{+} \cdots \mathrm{MeX}^{-}{ }_{m+1}
\end{aligned}
$$

これらの反応については泣)，たとえば $\mathrm{BF}_{3} \cdot \mathrm{AcOH}-$ $\mathrm{AcOH}$-スチレン系で, スチレンの二量体留分中に, 末 端アセテート基を有しない成分が約 10\% 含まれるとい う報告がある23)。またこのほかに溶媒，代純物など の連鎖移動などが考えられ，これらはカチオン重合に拉 いてポリマーの分子量を低下させる原因として重要であ るが, カチオンテロメリゼージョにおいてはほとんど 考慮されない

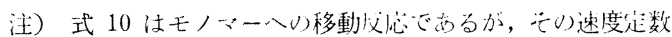
比 $\left(k_{t m} / k_{p}\right)$ は通常 $10^{-2}$ のオーダーである ${ }^{38)}$ 。

一方，一度生成したテロマーがテローゲンとして再び 反応に入り重合度が増加していくことは充分考えられる ことであり，とくにハロゲン化合物とオレフィンのカチ オンテロメリゼーションが, 式 11 のように付加反応の 繰り返しで逐次的に進むか，あるいは連鎖的に進むかが 議論の対象となる。

$$
\begin{aligned}
& \mathrm{XY}+\mathrm{M} \rightarrow \mathrm{YMX} \\
& \mathrm{YMX}+\mathrm{M} \rightarrow \mathrm{YM}_{2} \mathrm{X} \\
& \ldots \ldots \ldots \ldots \ldots \ldots \ldots \ldots \\
& \mathrm{YM}_{n-1} \mathrm{X}+\mathrm{M} \rightarrow \mathrm{YM}_{n} \mathrm{X}
\end{aligned}
$$

この場合，開始剤および成長カルボニウムイオンに対 する $\mathrm{YX}, \mathrm{YMX} \cdots \mathrm{YM}_{n} \mathrm{X}$ の相対的な反応性が問題にな る。ラジカルテロメリゼーションの場合，たとえばエチ レンと四塩化炭素では, テロマー $\mathrm{CCl}_{3}\left(\mathrm{CH}_{2} \mathrm{CH}_{2}\right)_{n} \mathrm{Cl}$ の 移動定数は $\mathrm{CCl}_{4}$ と比較して非常に小さいと考えられ， したがって，テロマーが再び应応にる確率は小さいと 考えられる。 
一方カチオンテロメリゼーションでは, テロマーがテ ローゲンと同等またはそれ以上の反応性を有する場合が ある。これは, 化合物の構造からある程度の予想をする ことができる。たとえばアルキルクロリド $(\mathrm{RCl})$ をテ ローゲンとする場合, タクソーダンがモノオレフィン $\left(\mathrm{CH}_{2}=\mathrm{CHR}^{\prime}\right)$ のときは, それらの 1 対 1 付加体は $\mathrm{RCH}_{2} \mathrm{CHR}^{\prime} \mathrm{Cl}$ であり, 他方, タクンーゲンが共役ジエ ンの場合は，たとえばブタジエンとの 1 対 1 付加体は $\mathrm{RCH}_{2} \mathrm{CH}=\mathrm{CHCH}_{2} \mathrm{Cl}$ (1,4 付加の場命) となる。後者は アリル型ハロダン原子を有し，再びテローゲンとして反 応化入りやすい。したがって, 上に述べたような例で は，モノマー自身の反応性を別にすれば，モノオレフィ ンと比較してジェンの方が重合度の大きいテロマーを与 える傾向がある。これとは逆に，アリル型八ロゲン化物 とモノオレフィンの反応では 1 対 1 付加体を多く生ずる 傾向がある ${ }^{311}$ 。

以下にカチオンテロメリゼーションに使用される開始 郕, テローダン, タクソーゲンおよび溶媒について簡単 に説明しょう。

\section{$2 \cdot 2$ 開 始 剂}

通常のカチオン重合触媒, すなわち $\mathrm{B}, \mathrm{Al}, \mathrm{Fe}, \mathrm{Ti}$, $\mathrm{Sn}, \mathrm{Zn}$ 等の八ログン化物, 硫酸, 過塩素酸等が用いら れる。イソプレンと塩化プレニルのカチオンテロメリゼ ーション (後節参照) での触媒活性の大きさは下記のよ らであった ${ }^{14 \mathrm{e}) 。 ~}$

$\mathrm{SnCl}_{4}>\mathrm{ZnCl}_{2}>\mathrm{BiCl}_{3}>\mathrm{ZrCl}_{4}>\mathrm{AlBr}_{3}$ $\mathrm{AlCl}_{3}>\mathrm{TiCl}_{4}>\mathrm{SbCl}_{3}>\mathrm{HgCl}_{2}$

同種の反応であるブタジエンと塩化クロチルのテロメ リゼーションでは ${ }^{4 \mathrm{c})}$

$$
\begin{aligned}
\mathrm{FeCl}_{3} & \simeq \mathrm{AlCl}_{3}>\mathrm{TiCl}_{4}>\mathrm{SbCl}_{5}>\mathrm{SnCl}_{4} \\
& \simeq \mathrm{BF}_{3} \mathrm{OEt}_{2}
\end{aligned}
$$

であった。

触媒の活性は，テローゲンとの反応でカルボニウムイ オンを生成する速度に相関すると考えられるが，塩素の 引抜きにより生成するカルボニウムイオンを経由する他 の種類の反応においても，これらの金属八ロゲン化物の 触媒活性の序列に一般性が無いことが知られている。た とえば， $\alpha$ フェニルェチルクロリドのラセミ化では39)

$\mathrm{SbCl}_{5}>\mathrm{SnCl}_{4}>\mathrm{BF}_{3}>\mathrm{HgCl}_{2}>\mathrm{TiCl}_{4}$ ベンゼンのアシル化では40)

$$
\mathrm{AlCl}_{3}>\mathrm{FeCl}_{3}>\mathrm{ZnCl}_{2}>\mathrm{SnCl}_{4}>\mathrm{TiCl}_{4}
$$
である。

金属八ログン化物以外では, 硫酸, スルホン酸, 過塩 素酸等の水素酸が開始剤として用いられる。これらの場 合には, これらの酸からのプロトンが直接タクソーゲン に付加して反応が開始されると考えられる。これらの中 では過塩素酸が最も強力な開始剤である。またカチオン 交換樹脂を用いた例もある ${ }^{18 \mathrm{~d}) 。 ~}$

\section{$2 \cdot 3$ テローゲン}

カチオンテロメリゼーションのテローゲンとして用い られるものは，それ自身，また沖開始剤との反応で容易 にプロトンまたはカルボニウムイオンを生成する物質で ある。式 2 および 3 の過程は, カチオン重合での触媒 と共触媒の反応に相当する。しかしカチオン重合で共触 媒となる物質が，カチオンテロメリザーションのテロー ゲンとして適当であるとは限らない。たとえば, 塩化第 二スズを触媒とするスチレンのカチオン重合で水および アルコールは共触媒として働くが，テローゲンとはなら ない。これは触媒との反応で生成するプロトンが, 多量 に存在する水またはアルコールにより溶媒和されて安定 化するためと考えられる。

カチオンテロメリゼーションのテローゲンとして通常 用いられるのは, アルキルおよびアルケニルハロゲン化 物, 八ロエーテル, カルボン酸, 酸無水物, 酸八ロゲン 化物, ホルムアルデヒド, ホルマールなどである。八ロ ゲン化金属を開始剤とするカチオンテロメリゼーション で八ロゲン化水素がテローゲンに用いられることがある が ${ }^{28)}$, この場合は, オレフィンと八ロゲン化水素の付加 体がまず生成し，これがテローゲンとして働くものと考 えられる。なぜなら，特殊な例を除いて，八ロゲン化水 素と八ロゲン化金属との間には直接相互作用がないこと が明らかにされているためである ${ }^{41}$ 。

$$
\begin{gathered}
\mathrm{HX}+\mathrm{MeX}_{m} \not-\mathrm{H}^{+} \cdots \mathrm{MeX}_{m: 1}^{-} \\
\mathrm{HX}+\mathrm{CH}_{2}=\mathrm{CHR} \longrightarrow \mathrm{CH}_{3} \mathrm{CHRX}^{\longrightarrow} \\
\mathrm{CH}_{3} \mathrm{CHRX}+\mathrm{MeX}_{m} \rightleftharpoons \mathrm{CH}_{3} \mathrm{CHR} \cdots \cdots \mathrm{MeX}_{m+1}^{-}
\end{gathered}
$$

\section{4 タクソーゲン}

カチオン重合性のモノマーが用いられる。現在までお もにイソプレン, ブタジェン，スチレンが使用されてき た。オレフィン以外では，わずかにエチレンオキシドお よびテトラヒドロフランが報告されているのみである。 カチオンテロメリゼーションにおいてはとくにイソプレ ン関係の文献が多いが，これはテルペン化合物を一段階 で合成する方法として注目されているためである。タク ソーゲンの構造と反応性の問題はカチオン重合の方面で 研究されているのでここでは省略する。

\section{5 溶媒}

カチオンテロメリゼーションは通常溶液中で行なわ れ, 反応速度およびテロマーの重合度に与える溶媒の影 響は大きい。とくに溶媒の塩基性（開始剤およびカルボ ニウムイオンとの相互作用の大小）が重要であり, 塩基 性が大きくなるにしたがい, 開始剤との相互作用が大き くなり，開始剤とテローゲンの反応を抑制する。通常は 八ロゲン化炭化水素が用いられるが, 含酸素または含窒 素溶媒（エーテルおよびニトロ化合物など）を用いて開 
始剂の活性を適度に抑制し，かつ生長カルボニウムイオ ンとの相互作用により, 反応性に変化をもたらすことも 川能である。また，これらの化合物を反応系に少量添加 して開始剤の活性および反応の選択性に変化をもたらす 試みも行なわれている ${ }^{4 d}$ 。

\section{3 カチオンテロメリゼーションの実際例}

表-1にこれまで文献に現われたカチオンテロメリゼ ーションのタクソーゲンとテローゲンを整理してみた。

表-1 カチォンンテメリゼーションに扮ける 代表的なタクソーゲンとテローゲン

\begin{tabular}{|c|c|c|}
\hline タクソーゲン & テローゲン & 文献 \\
\hline グタジェン & 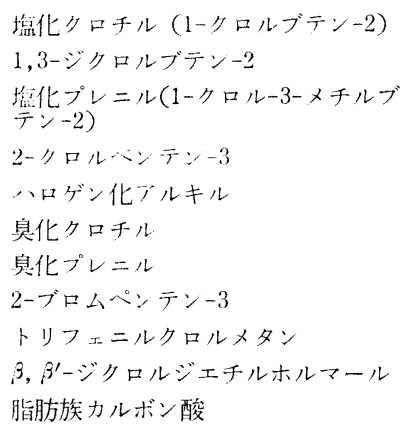 & $\begin{array}{r}4 \\
5 \\
6 \\
7 \\
8 \\
9 \\
10 \\
10 \\
11 \\
12 \\
13\end{array}$ \\
\hline イソプレン & 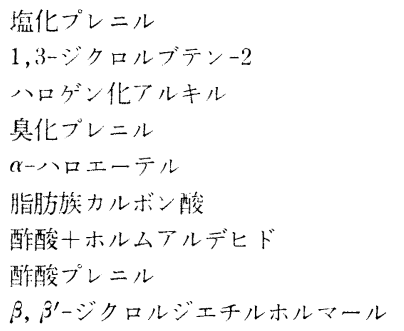 & $\begin{array}{r}14 \\
15 \\
8 \\
16 \\
17 \\
18 \\
19 \\
20 \\
12\end{array}$ \\
\hline クロロプレン & 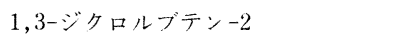 & 21 \\
\hline スチレン & 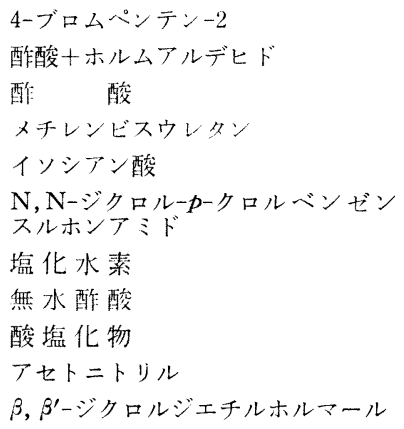 & $\begin{array}{l}22 \\
23,24 \\
23 \\
25 \\
26 \\
27 \\
28 \\
29 \\
30 \\
23 \\
12\end{array}$ \\
\hline $\begin{array}{l}\text { その他のモノ } \\
\text { オレフィン }\end{array}$ & $\begin{array}{l}\text { アリル型ハロゲン化物 } \\
\text { イソシアン酸 } \\
\text { イソシアニド } \\
\text { アセタール }\end{array}$ & $\begin{array}{l}31 \\
26 \\
32 \\
33\end{array}$ \\
\hline $\begin{array}{l}\text { エチレンオキ } \\
\text { シド }\end{array}$ & エチレンクロルヒドリン & 34 \\
\hline $\begin{array}{l}\text { テトラヒドロ } \\
\text { フラン }\end{array}$ & 無 水酢酸 & 35 \\
\hline
\end{tabular}

生成テロマーの構造が充分確鯰されていないもの，また タクソーゲンとテローゲンの 1 対 1 付加体のみを研究対 象としたものも多い。テロマーの重合度は，テローゲン の種類, テローゲン/タクソーゲンの仕込み比, 反応率, 溶媒などにより変化するが，その様子は個々の反応で異 なり一般化することは困難である。以下に代表的な夕ク ソーゲンであるブタジエン，イソプレンおよびスチレン の例を紹介しよう。

\section{1 ブタジェン}

ブタジエンをはじめとする共役ジエン化合物に対する 極性化合物の付加は，1，4一結合や1,2-結合など複数の結 合型式が可能であり，したがってカチオンテロメリゼー ションにより生成するテロマー中のジエン単位は, 異な る結合型式を有すると考えられる。また，テロマー中の 残存二重結合がプロトンまたはカルボニウムイオンを付 加する能力を有するため，テロマーの構造は非常に複雑 となり，異性体の数も多い。たとえば，ブタジエン（T) と塩化クロチル(II)のカチオンテロメリゼーションで生 成するテロマー（III）のうちで $n=2$ の部分を考えた場合 (式 13)，付加が Markovnikov の法則にしたがうとして また， cis と trans の異性体を考えないとしても IV か ら VII の 4 種類の鎖状異性体および VII と IX の環状異性 体が存在する。イソプレンおよびクロロプレンなどの非 対称ジエンになると異性体の数はさらに多くなり，また 三荲体以上では，その数は幾何級数的に増加する。

$$
\begin{aligned}
\mathrm{CH}_{2} & =\mathrm{CH}-\mathrm{CH}=\mathrm{CH}_{2}+\mathrm{CH}_{3}-\mathrm{CH}=\mathrm{CH}-\mathrm{CH}_{2} \mathrm{Cl} \\
& (\mathrm{I}) \\
\rightarrow & \mathrm{H}\left(\mathrm{C}_{4} \mathrm{H}_{6}\right){ }_{n} \mathrm{Cl}
\end{aligned}
$$

(III)

$\mathrm{CH}_{3}-\mathrm{CH}=\mathrm{CH}-\mathrm{CH}_{2}-\mathrm{CH}_{2}-\mathrm{CH}=\mathrm{CH}-\mathrm{CH}_{2} \mathrm{Cl}(\mathrm{IV})$

$\mathrm{CH}_{3}-\mathrm{CH}=\mathrm{CH}-\mathrm{CH}_{2}-\mathrm{CH}_{2}-\mathrm{CHCl}-\mathrm{CH}=\mathrm{CH}_{2}(\mathrm{~V})$

$\mathrm{CH}_{2}=\mathrm{CH}-\mathrm{CH}-\mathrm{CH}_{2}-\mathrm{CH}=\mathrm{CH}-\mathrm{CH}_{2} \mathrm{Cl}$ $\stackrel{!}{\mathrm{C}} \mathrm{H}_{3}$

$\mathrm{CH}_{2}=\mathrm{CH}-\mathrm{CH}-\mathrm{CH}_{2}-\mathrm{CHCl}-\mathrm{CH}=\mathrm{CH}_{2}$ $\stackrel{!}{\mathrm{C}} \mathrm{H}_{3}$
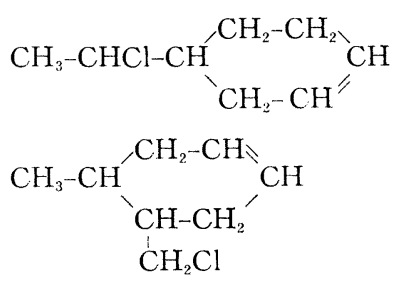

式 13 の反応はルイス酸を触媒として咩細に研究され だ)。研究結果を要約すると

1）塩化クロチル(II)はブタジェンに塩化水素を付加 して合成するが，その際副生する異性体 $(\mathrm{X})$ をテローゲ ンに用いてもテロマーの構造は変わらない。これはIIお よびXと開始剂の反応で同一のカルボニウムイオン $(\mathrm{XI})$ 
が生成して成応が谁むことを示す。

$\mathrm{CH}_{3}-\mathrm{CHCl}-\mathrm{CH}=\mathrm{CH}_{2}$

(X)

$\mathrm{CH}_{3}-\mathrm{CH} \overbrace{-\mathrm{CH}} \sim \mathrm{CH}_{2}$

(XI)

2) テロマーヤのブタジエン単位の結合は,約 $80 \%$ が 1,4-であり約 $20 \%$ が 1,2-結合であいた。 $n=2$ テロマ 一はほぼ種類の買性体からなり，1-クロルオクタジエ ン -2,6が約 $60 \%$ を占める。

3) 反応摔の增加上ともに，テロマー中の $n=2$ 成分 の比率が減少する。また, 什込及の [II]/[1]比の増加 はテロマーの重合度を減少させるが，IIの重合が増加す る。

4)高級テロマー中の塩素含有著は临の構造式から部 算されるよりも多く，杰た不飽和度は小さい。すなわち 枝分れ（式 14）拉よび環化度応（式 15）尔どの副反応

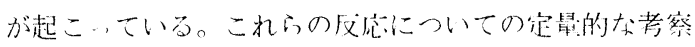
も行なわ机ている。

$$
\begin{aligned}
& \sim \mathrm{CH}_{2}+\sim \mathrm{CH}_{2}-\mathrm{CH}=\mathrm{CH}-\mathrm{CH}_{2} \sim \\
& \mathrm{CH}_{2} \sim \\
& \rightarrow \sim \mathrm{CH}_{2}-\stackrel{+}{\mathrm{C}} \mathrm{H}-\stackrel{+}{\mathrm{C}} \mathrm{H}-\mathrm{CH}_{2} \sim
\end{aligned}
$$

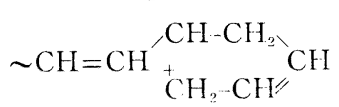

$$
\begin{aligned}
& \text {, } \sim \stackrel{+}{\mathrm{C}} \mathrm{H}-\mathrm{CH}_{\mathrm{CH}_{2}-\mathrm{CH}^{\prime}}^{\mathrm{CH}-\mathrm{CH}_{2}} \mathrm{CH}
\end{aligned}
$$

5）エーテル㧍よびニトロ化合物の溶媒中では，八口 ゲン化涔化水素中より父芯がゆるやかで, 低重合度のテ ロマーが得られ，かつ副反応が抑制される。

一方，硫酸また汇過塩素酸触媒に上るブタジエンと酢 酸またはプロピオン酸のテロメリゼーションで'3)，ブタ ジエン単位を有するカルボン酸エステルが得られてい る。この場合にも，炭化水素打よび環状化合物が副生す るが，たとえば，ブタジェンの転化率 $38 \%$ で $\mathrm{C}_{8}$ アセ テート $38 \%$ を有する混命物が得られる。

\section{$3 \cdot 2$ イソプレン}

前述したように, 其役ジエン化合物のカチオンテロメ リゼーションは, 複雑な構造のテロマーを生成し, その 分離, 同定には困難が伴なら。それにもかかわらずイソ プレンのカチオンテロメリゼーションの研究がよく行な われてきたのは, 生成物の利用価值が大きいためであ る。すなわち，香料合成の中間体であるゲラニオール， ビタミンAの中間体であるシトラール，コン虫の生理活 性物質であるファルネソール等の合成を目的とするもの が多い。

イソプレンと䣷酸18a) または八ロゲン化酢酸 ${ }^{18 \mathrm{C})}$ とのテ ロメリゼーションでテルペンアルコールまたはそのエス テルを合成する試みは 1940 年代に行なわれている。前 者は無機酸を開始剤として用い, 後者はテローゲンが開
始棛を兼ねる。

1950 年代になり，イソプレン (XII) と塩化プレニル (XIII)のテロメリゼーションによりゲラニルクロリド (XIV) を合成する方法がり連の研究者により研究され, 一連の報告が出された ${ }^{14)}$ 。これはシトラールを合成品で 安価に供給することを目的としたものである（式 16）。 $\mathrm{CH}_{3}$

$$
\begin{aligned}
& \mathrm{CH}_{2}=\mathrm{C}-\mathrm{CH}=\mathrm{CH}_{2}+\mathrm{HCl} \rightarrow \underset{\mathrm{CH}_{3}}{\mathrm{CH}_{3}}>\mathrm{C}=\mathrm{CH}-\mathrm{CH}_{2} \mathrm{Cl} \\
& \text { (XII) } \\
& \text { (XIII) } \\
& \mathrm{CH}_{3} \\
& \mathrm{XII}+\mathrm{XIII} \rightarrow \underset{\mathrm{CH}_{3}}{\mathrm{CH}_{3}}>\mathrm{C}=\mathrm{CH}-\mathrm{CH}_{2}-\mathrm{CH}_{2}-\mathrm{C}=\mathrm{CH}-\mathrm{CH}_{2} \mathrm{Cl} \\
& \text { (X IV) } \\
& \text { 十その他の生成物 }
\end{aligned}
$$

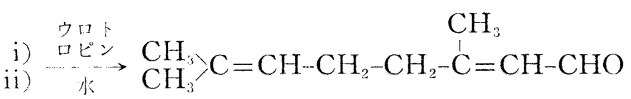

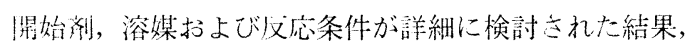
開始剂としては塩化第二スズが最もすぐれているが， XIV の收率をよくするためには，テロメリゼーションの 仪応率を $20 \%$ 程度におさえることが必要である。これ は一度生成した XVI が再び反応に入るためである。付 加はおもに Markovnikov 則に従らが， $\mathrm{C}_{10}$ 混合物中に はほかにリ十リルクロリド, バンジェリルクロリドなどが含まれる。Sommlet 反応 によりXIV をシトラールに変換する過程を含めた連続装 置も設計されている。1 部さクルの XIV の収率が低い こと, 異性体との分離が困難なことなどがこの反応の欠 点であるが，その後も開始剤の変性 ${ }^{14 \mathrm{~d}}$ 反応条件の一定 化 $^{14 \mathrm{f})}$, 反応の停止法 ${ }^{14 \mathrm{~g})}$, 生成物の分離技術 ${ }^{14 \mathrm{~h})}$ などの 改良が進められている。

\section{$3 \cdot 3$ スチレン}

塩化第二スズを開始剤とするスチレンと塩化水素 ${ }^{28}$, 酸塩化物 ${ }^{30}$ および無水酢酸29)のテロメリゼーションで, それぞれ XV，XVI および XVII の構造を有するテロマ 一が得られている。

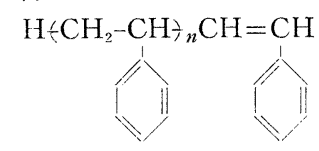

$(\mathrm{XV})$

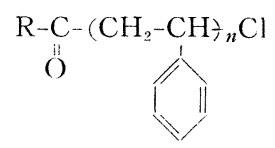

$(\mathrm{X}$ VI $)$

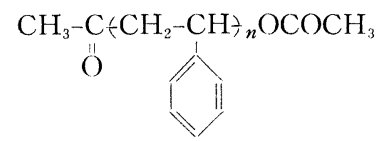

(XVII)

$$
\begin{aligned}
& \mathrm{R}=\mathrm{CH}_{5}, \mathrm{C}_{2} \mathrm{H}_{5}, n-\mathrm{C}_{3} \mathrm{H}_{7}, \text { iso- } \mathrm{C}_{3} \mathrm{H}_{7}, \text { sec }-\mathrm{C}_{4} \mathrm{H}_{9}, \\
& \text { tert }-\mathrm{C}_{4} \mathrm{H}_{9}
\end{aligned}
$$

$\mathrm{XV}$ では $n=1 \sim 4$ が XVI とXVII では $n=1$ のみが單 離されている。また，XVII については高級テロマーの構 造も研究されている。XVI およびXVII の $n=1$ の化合 
物は, アルカリで容易に脱塩化水素または脱酢酸してベ ンザルアセトンその他を与える。<smiles>[R]C(=O)C=Cc1ccccc1</smiles>

(X VIII)

XV の場合, 未端不飽和結合は, 生長カルボニウムイオ ンからプロトンが脱離して生成するとされているが,

XVIの場合は，末端に塩素を有するテロマーが主生成物 である。

ホルムアルデヒドと酶酸の混合物をいわば複合テロー ゲンとして用い，両端に水酸基およびアセテート基を有 するスチレンテロマー(XIX) が合成されている ${ }^{23), 24) 。 ~}$

度応は下記の機構で進むとされている。XIX を加水分解 して得られるジオールとジイソシアナートの反応でポリ ウレタンを合成することができる ${ }^{24 a)}$ 。

$\mathrm{CH}_{3} \mathrm{COOH}+\mathrm{BF}_{3} \cdot \mathrm{O}\left(\mathrm{C}_{2} \mathrm{H}_{5}\right)_{2}$ $\rightarrow\left[\mathrm{CH}_{3} \mathrm{COO} \cdot \mathrm{BF}_{3}\right]-\mathrm{H}^{+}+\left(\mathrm{C}_{2} \mathrm{H}_{5}\right)_{2} \mathrm{O}$

$[\mathrm{B}]-\mathrm{H}^{+}+\mathrm{CH}_{2} \mathrm{O} \rightarrow[\mathrm{B}]-{ }^{+} \mathrm{CH}_{2} \mathrm{OH}$

$[\mathrm{B}]-\stackrel{+}{\mathrm{C}} \mathrm{H}_{2} \mathrm{OH}+\mathrm{CH}_{2}=\mathrm{CHPh}$ $\rightarrow \underset{\mathrm{Ph}}{\mathrm{HOCH}_{2} \mathrm{CH}_{2} \stackrel{+}{\mathrm{C}} \mathrm{H}[\mathrm{B}]^{-}}$

$\mathrm{HOCH}_{2} \mathrm{CH}_{2} \stackrel{+}{\mathrm{C}} \mathrm{H}[\mathrm{B}]^{-+}+(n-1) \mathrm{CH}_{2}=\mathrm{CHPh}$ $\stackrel{!}{\mathrm{Ph}}$

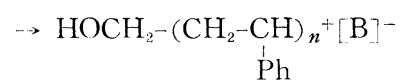

$$
\begin{aligned}
& \mathrm{HOCH}_{2}-\left(\mathrm{CH}_{2}-\mathrm{CH}\right)_{n}{ }^{+}[\mathrm{B}]^{-} \\
& \mathrm{Ph} \\
& \rightarrow \mathrm{HOCH}_{2} \leftarrow \mathrm{CH}_{2}-\mathrm{CH}>{ }_{n} \mathrm{OCOCH}_{3}+\mathrm{BF}_{3} \\
& \stackrel{\mathrm{Ph}}{(\mathrm{XIX})} \\
& {[\mathrm{B}]^{-}=\left[\mathrm{CH}_{3} \mathrm{COO} \cdot \mathrm{BF}_{3}\right]^{-}}
\end{aligned}
$$

停止反応は抢もに対了ニオンとの反応で, 生長カルボニ ウムイオンからのプロトン脱離は少ない。をた, 硫酸触 媒でアセトニトリルをテローゲンに用いて末端にアミド 基を有するテロマー $(\mathrm{XX})$ も得られている ${ }^{23)}$ 。

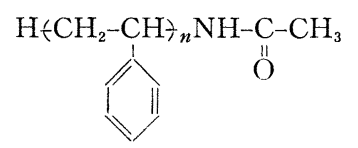

$(\mathrm{XX})$

そのほか， $\beta, \beta^{\prime}$-ジクロルジエチルホルマール ${ }^{12}$ およ びメチレンビスウレタン ${ }^{25) を テ ロ ー ケ ゙ ン と し て ， そ れ そ ゙ ~}$ れ構造 XXI およびXXII のテロマーが合成されている。

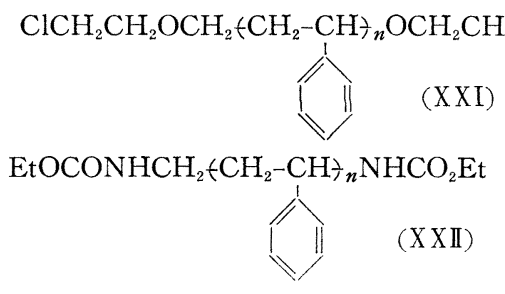

\section{4 おりに}

カチオンテロメリゼーションはラジカルテロメリゼー ションと比較して系統的に研究された例が少なく, とく に反応機構についての詳細な研究はこれからの課題とし て残されている。テローゲンとタクソーグンの組合せ も，いろいろ扔もしろいものが考えられ，とくにテロー ゲンとして新しい種類の化合物を開拓する余地もあると 思われる。また，広い意味での触媒規制といら考えか ら, 重合度規制, 立体規則性テロマーの合成といら可能 性もあるがまだほとんど研究されていない。

カチオン重合は最近かなり解明されてきたが, 開始, 連鎖移動㧍よび停止反応に不明な点も残されているよう である。テロマーの重合度が低く, 末端基の構造決定が 比較的容易な点を利用して, カチオンテロメリゼーショ ンをカチオン重合機構の研究に用いることも考えられ る。いずれにしても，カチオンテロメリゼーションにお いては, デー夕の蓄積が薄く, 未開拓の分野が多いとい ら印象がある。より多くの人々がこの方面に関心を持た れることを願う次第である。

\section{（昭和 47 年 7 月 15 日受理） \\ 文献}

1) J. Harmon, U.S., 2,390,099 (1945) など

2) a) 高木, 浅原, 有合化, 19, 172 (1961); b) 武久, 石 油誌, 9, 134 (1966)

3) 浅原, 妹尾, 田中, 油化学, 20, 385 (1971)

4) a) A.A. Petrov, Kh.V. Bal' yan, L.I. Bunina-Krivorukova, T.V. Yakovleva, Zhur. Obshch. Khim., 29, 1576 (1959); b) T. Asahara, H. Kise, Bull. Chem. Soc. Japan, 39, 2739 (1966); c) 40, 1941 (1967); d) 40, 266! (1967)

5) A.A. Petrov, Kh.V. Bal'yan, L.I. Bunina-Krivorukova, T.V. Yakovleva, Zhur. Obshch. Khim., 29, 2518 (1959)

6) A.A. Petrov, N.A. Razumova, Zhur. Obshch. Khim., 28, 2138 (1958)

7) A.A. Petrov, N.A. Razumova, M.L. Genusova, Zhur. Obshch. Khim., 28, 2132 (1958)

8) A.A. Petrov, K.V. Leets, Zhur. Obshch. Khim., 26, 1113 (1956)

9) T. Asahara, H. Kise, Bull. Chem. Soc. Japan, 42, 1065 (1969)

10) L.A. Cherkasova, Kh.V. Bal'yan, L.M. Zubritskii, Zhur. Obshch. Khim., 34, 1917 (1964)

11) Z.N. Kolyaskina, A.A. Petrov, Zhur. Organ. Khim., 2, 1762 (1966)

12) T.A. Fokina et al., Vysokomolekul. Soedin., 8, 207 (1966); Chem. Abstr., 64, $19337 \mathrm{~g}$

13) E.L. Jenner, R.S. Schreiber, J. Amer. Chem. Soc., 73, 4348 (1951)

14) a) K.V. Leets, Zhur. Obshch. Khim., 28, 1823 (1957) ; b) A.A. Petrov et al, Zhur. Obshch. Khim., 28, 1435 (1958) ; c) A.A. Petrov et al, Zhur. Obshch. Khim., 29, 1876 (1959); d) 浅原, 豊田, 木瀬, 工化, 72, 1529 (1969) ; e) K.V. Leets, E.Kh. Liiv, Zhur. Organ. Khim., 1, 626 (1965) ; f) U.S.S.R. 221, 291 
(1968), Chem. Abstr., 69, 105852 (1968); g) Czech. 123, 639 (1967) ; h) K.V. Leets, Zhur. Obshch. Khim., 31, 1869 (1961)

15) A.L. Klebanskii, Zhur. Obshch. Khim., 28, 881 (1958)

16) L.A. Cherkasova, Zhur. Obshch. Khim., 34, 1917 (1964)

17) a) A.N. Pudorik, Zhur. Obshch. Khim., 26, 1635 (1956); b) A.A. Petrov et al., 28, 1426 (1958); c) H. Gross, E. Höft, Angew. Chem. Int. Ed., 6, 335 (1967)

18） a) T. Lennartz, Ber., 76 B, 831 (1943); b) 田中, 片 桐, 竹下, 日化, 89, 65 (1968); c) U.S., 2,460,291 (1949) ; d) A. Erm, K. Laats, Esti. NSV Tead. Akad. Toim., Keem., Geol., 16, 37 (1967), Chem. Abstr., 67, 90950 (1966)

19）古川, 山下, 佐藤, 高化, 22, 366 (1965)

20）田中, 片桐, 高部, 工化, 74, 1162 (1971)

21) M.G. Barkhudaryan, A.L. Klebanskii, Sbornik. Nauch. Trudov, Erevan, Politekh. Inst. in $K$. Marksa, 1957, 55, Chem. Abstr., 55, $9255 \mathrm{~d}$

22) a) L.A. Cherkasova, Kh.V. Bal'yan, A.A. Petrov, Zhur. Obshch. Khim., 34, 2917 (1964) ; b) 34, 2926 (1964)

23) D.D. Coffman, E.L. Jenner, J. Amer. Chem. Soc., 76, 2685 (1954)

24） a) 古川, 山下, 传藤, 高化, 22, 363 (1965); b) K. Plochocka, Polymery, 11, 208 (1966), Chem. Abstr., 66, 18885 q ; c) Pol. 51,700 (1966), Chem. Abstr., 68, $3351 \mathrm{c}$
25）和田, 小田, 工化, 69, 1361 (1966)

26) Ger. 1,944,343 (1970), Chem. Abstr., 72, $133406 \mathrm{v}$

27) N.A. Rybarova, R.Kh. Freidlina, Izv. Akad. Nauk SSSR, Ser. Khim., 1971, 429, Chem. Abstr., 74, $125051 \mathrm{~b}$

28) G. Williams, H. Thomas, J. Chem. Soc., 1948, 1867

29）浅原, 木瀬, 阿部, 工化, 73, 790 (1970)

30）浅原, 佐藤, 小林, 木瀬, 未発表

31) a) M.L. Genusov, A.A. Petrov, Zhur. Obshch. Khim., 33, 2859 (1963); b) L.A. Cherkasova, Kh.V. Bal'yan, A.A. Petrov, Zhur. Obshch. Khim., 34, 2917 (1964); c) M.L. Genusov, A.A. Petrov, Zhur. Organ, Khim., 1, 2105 (1965)

32) T. Saegusa, N. Takaishi, Y. Ito, Polym. J., 1, 532 (1970)

33) S.M. Makin, Zhur. Obshch. Khim., 32, 3161, 3166. (1962)

34）阿部, 渡辺, 工化, 66, 471 (1963)

35) B.A. Rozenberg, E.P. Babin., Zhur. Organ. Khim., 1, 1102 (1965)

36) 東村 “カチオン重合” p. 68 (1971), 化学同人, 京都

37) P.H. Plesch ed. "The Chemistry of Cationic Polymerization", p. 286 (1963), Pergamon Press, Oxford

38） a）文献 36 , p. $150 ;$ b) 文献 37

39) G.A. Olah "Friedel-Crafts and Related Reactions" Vol. 1, p. 854 (1963), Interscience Publishers, New York

40) N.O. Colloway, Chem. Rev., 17, 327 (1935)

41) 文献 36, p. 30 